\title{
SEDE PRÉ-OPERATORIA: A PERCEPÇAO DA CRIANÇA
}

\section{Pôster}

Autores deste trabalho:

ANDRESSA APARECIDA RIVIERA: Universidade Estadual de Londrina

Mariana Campos Campana: Universidade Estadual de Londrina

Lígia Fahl Fonseca: Universidade Estadual de Londrina

Área do Trabalho: Enfermagem pediátrica

Número de inscrição: 4826

Data da submissão:01/08/2016 às 23:02

\section{Justificativa}

Uma das consequências do jejum prolongado para a criança no pré-operatório é a sede. Esse desconforto é frequentemente observado em crianças durante o período perioperatório. Não há estratégias padronizadas para o manejo da sede em crianças e usualmente mantêm-se a criança em jejum por períodos demasiadamente prolongados. A criança geralmente utiliza formas de linguagem não verbais para se expressar a respeito das novas experiências vivenciadas durante o jejum. É nesse contexto que o desenho se revela importante pois, através dele, a criança acessa seu interior e expressa a subjetividade de seus sentimentos, angústias e percepções.

\section{Objetivo(s)}

Apreender a percepção da criança sobre a sede pré-operatória, seus mecanismos de enfrentamento e as repercussões na hospitalização.

\section{Método(s)}

Estudo qualitativo utilizando o Procedimento Desenho-Estória com Tema para a coleta de dados e análise de conteúdo segundo o método proposto por Bardin. Participaram da pesquisa 15 crianças no pré-operatório imediato que aguardavam cirurgia em um hospital universitário, aos quais foi solicitado que desenhassem sua operação e aproximando-se do tema proposto, como era aguardar pela cirurgia em jejum. 


\section{Resultado(s)}

Emergiram duas categorias: Sofrendo com a sede e Enfrentando a sede e o jejum. As crianças representam a sede como sensação desconfortável, pior até que a fome. Algumas procuram se distrair brincando, outras molham a boca para diminuir a sede e há as que inclusive tentam burlar o jejum.

\section{Conclusão(ões)}

Esse momento a percepção da sede pela criança é desenvolvida, por vezes, diferentemente da percepção que apresentavam fora do contexto cirúrgico. A representação, agora, é influenciada por múltiplos fatores, físicos, sociais e emocionais, caracterizada pelo aspecto de proibição, negação que é até, muitas vezes, interpretada como falta de cuidado. Elas, dessa forma, percebem a sede pré-operatória como causadora de grande desconforto, principalmente pelo ressecamento da cavidade orofaríngea que apresentam. Desenvolvem formas de enfrentamento passivas diante desse problema, aceitando vivenciar a sede e utilizando artifícios para se distrair e não pensar na sede. Esse sofrimento, no entanto, lhes causa tanta ansiedade que, por vezes, chegam a burlar regras e tentar beber água escondido. 